Available online at https://jurnal.stmikroyal.ac.id/index.php/jurdimas

\title{
PEMANFAATAN KONSELING ONLINE PADA GURU SD DI KALIMANTAN TENGAH
}

\author{
Berkat $^{1}$, Bhayu Rhama ${ }^{2}$, Wahyuni Christiany Martono ${ }^{3}$, \\ Elisabeth Fransisca Saragi Sitio ${ }^{3}$, Ferry Setiawan ${ }^{2}$, Ahmad Saefulloh ${ }^{4 *}$ \\ ${ }^{1}$ Prodi Agribisnis, Fakultas Pertanian Universitas Palangka Raya \\ ${ }^{2}$ Prodi Ilmu Administrasi Negara, FISIP Universitas Palangka Raya \\ ${ }^{3}$ Prodi PGPAUD FKIP Universitas Palangka Raya \\ ${ }^{4}$ Prodi PPKn FKIP Universitas Palangka Raya \\ email: *saefulloh@fkip.upr.ac.id
}

\begin{abstract}
The current covid-19 pandemic season pays special attention to students who study at home through online methods. The thing of concern is the frequent occurrence of violence in elementary school age children while studying due to the limitation of parents as substitute teachers during online learning. Parents of students with all their activities are required to help and assist their children in making school work. So the phenomenon that occurs in the field is the uncontrolled control of parental emotions towards children, so that online learning seems to be a frightening specter for elementary students. The purpose of implementing this Online Counseling Guidance is to provide insight to elementary school teachers who are members of the Indonesian Teachers Association (PGRI) Central Kalimantan regarding the mechanism for utilizing counseling which can be done online through the Competency Assessment and Career Development Service Center (PPAKPK) web. The method of implementing this service is carried out online through Conference Via Zoom and tutorials on using the web on a YouTube account which are distributed to Bimtek participants. The results obtained at this Bimtek show that all Bimtek participants are interested in the use of Online Counseling to serve as a means of consulting both students to teachers or guardians of students to teachers or teachers to psychiatrists who can be contacted when the teacher needs student problem solving.
\end{abstract}

Keywords: online counseling; elementary school teacher; central kalimantan

Abstrak: Musim pandemi covid-19 saat ini memberi perhatian khusus bagi para siswa yang belajar di rumah melalui metode daring. Hal yang menjadi perhatian adalah sering terjadinya kekerasan pada anak usia SD saat belajar dikarenakan faktor keterbatasan orang tua sebagai guru pengganti selama pembelajaran daring. Orang tua siswa dengan segala kesibukannya dituntut untuk membantu dan mendampingi anak-anak mereka membuat Pekerjaan Sekolah. Maka fenomena yang terjadi di lapangan adalah pengendalian emosi orang tua yang tidak terkendali kepada anak, sehingga pembelajaran daring terkesan menjadi momok yang menakutkan bagi para siswa SD. Tujuan dari pelaksanaan Bimtek Konseling Online ini adalah untuk memberikan wawasan kepada para Guru SD yang tergabung di dalam Persatuan Guru Republik Indonesia (PGRI) Kalimantan Tengah terkait mekanisme pemanfaatan konseling yang dapat dilakukan secara daring melalui web Pusat Pelayanan Asesmen Kompetensi dan Pengembangan Karir (PPAKPK). Metode pelaksanaan pengabdian ini dilakukan dengan cara daring melalui Conference Via Zoom dan tutorial penggunaan web pada akun youtube yang dibagikan kepada para peserta Bimtek. Hasil yang diperoleh pada Bimtek ini menunjukan bahwa seluruh peserta Bimtek tertarik dengan pemanfaatan Konseling Online untuk dijadikan sebagai sarana konsultasi baik siswa kepada guru ataupun wali murid kepada guru ataupun Guru kepada ahli Psikiater yang dapat dihubungi saat Guru membutuhkan pemecahan masalah siswa.

Kata Kunci: konseling online; guru sd; kalimantan tengah 
Available online at https://jurnal.stmikroyal.ac.id/index.php/jurdimas

\section{PENDAHULUAN}

Pemanfaatan teknologi informasi dan komunikasi (TIK) sudah menyentuh hampir seluruh aspek kehidupan masyarakat (Yaumi, 2018). Termasuk salah satunya dalam mendukung pengelolaan sekolah (Suwarsih, 2011). Rencana Strategis Departemen Pendidikan Nasional, secara eksplisit menyebutkan tiga pilar kebijakan pendidikan nasional, yaitu: perluasan dan pemerataan akses, peningkatan mutu dan relevansi serta daya saing, penguatan tata kelola, akuntabilitas dan citra publik pendidikan, untuk mewujudkan pendidikan yang bermutu, akuntabel, murah, merata dan terjangkau rakyat banyak (Marzuki, 2012). Peran strategis teknologi informasi dan komunikasi (TIK) untuk pilar pertama, yaitu perluasan dan pemerataan akses pendidikan, diprioritaskan sebagai media pembelajaran jarak jauh (Latip, 2020).

Sedangkan untuk pilar kedua, peningkatan mutu, relevansi dan daya saing, peran teknologi informasi dan komunikasi (TIK) diprioritaskan untuk penerapan dalam pendidikan/proses pembelajaran. Terakhir, untuk penguatan tata kelola, akuntabilitas dan citra publik, peran teknologi informasi dan komunikasi (TIK) diprioritaskan untuk sistem informasi manajemen secara terintegrasi (Anon, 2015). Namun pemanfaatan ini belum merata di seluruh tingkat pendidikan. Penerapan teknologi informasi dan komunikasi (TIK) di TK adalah untuk mengolah nilai, membuat rekap absensi, membuat presentasi untuk mengajar, surat menyurat maupun laporan kerja (Suryana, 2017). Guru perlu selektif dalam mendidik siswa mengerjalakan pekerjaan rumah, apalagi berbasis internet tugas yang diberikan (Saefulloh, 2018). Maka pada musim pandemi saat ini metode penyampaian informasi yang dilakukan guru cenderung menggunakan media whatsApp group sebagai sarana pembelajaran (Saefulloh, 2019). Pembelajaran pada tingkat SD harus menarik sesuai dengan tingkat usia siswa (Herliandry, Nurhasanah, Suban, \& Kuswanto, 2020).

Salah satu yang menghadapi masalah tersebut adalah Guru SD Anggota PGRI di Kalimantan Tengah, Di mana dapat diketahui bahwa masih ditemukannya Sumber Daya Manusia di Lingkungan Tenaga Pendidik yang masih belum sesuai dengan konsep analisa jabatan, khususnya untuk Jobfit. Hal ini yang mendasari adanya pengabdian kepada masyarakat, khususnya para Tenaga Pendidikan yaitu Guru SD di Lingkungan Provinsi Kalimantan Tengah.

Dalam rangka pemenuhan Tridharma Perguruan Tinggi, berbagai macam bentuk pengabdian terhadap sesama hendaknya dapat dilakukan oleh Dosen dan dapat melibatkan mahasiswa Universitas Palangka Raya. Salah satu program pengabdian yang dilakukan adalah dalam pembuatan website yang pada website tersebut terdapat aplikasi Konseling Online dan Analisa Jabatan Online. Website ini merupakan wadah pembekalan guru dan dosen atau pembinaan mahasiswa untuk menyalurkan minat dan bakatnya dalam mengamalkan profesionalisme disiplin ilmu ke tengah masyarakat. Manfaat lain dari website ini adalah menciptakan rasa kepekaan terhadap sesama yang membutuhkan. Adapun tujuan dan manfaat yang diharapkan dalam pengabdian masyarakat bagi Guru SD di provinsi Kalimantan Tengah, ini 
Available online at https://jurnal.stmikroyal.ac.id/index.php/jurdimas

adalah membangun aplikasi konseling online melalui Website yang dapat diakses melalui smartphone, melatih guru menggunakan aplikasi konseling online, melakukan uji coba aplikasi ke mitra (Guru SD yang masuk dalam anggota PGRI). Terakhir evaluasi aplikasi dan kemampuan guru menggunakan aplikasi hingga mampu memperoleh hasil

\section{METODE}

Pelaksanaan kegiatan pelatihan dilakukan dengan membuat instrumen dan konten materi konseling, mitra dan tim melakukan simulasi konseling online dalam bentuk Bimtek kepada para Guru SD yang mewakili di Kalimantan Tengah, serta dengan melakukan revisi instrumen dan validasi instrumen tes. Indikator kegiatan yang digunakan adalah dengan membangun aplikasi Online, melatih guru-guru SD yang ada di Kalimantan Tengah menggunakan aplikasi, uji coba aplikasi ke Mitra Pengabdian dalam hal ini adalah guru yang tergabung di dalam anggota PGRI Provinsi Kalimantan Tengah, serta melakukan evaluasi aplikasi

Dalam Bimbingan Teknik (Bimtek) yang diadakan pada tanggal 26 Oktober 2020 melalui zoom meeting diperuntukkan kepada 25 orang peserta yang terdiri dari para Guru SD di Lingkungan Provinsi Kalimantan Tengah. Untuk kelancaran acara pelatihan bagi para Guru SD di Lingkungan Provinsi Kalimantan Tengah, perlu dilakukan penyusunan acara seperti yang ditampilkan pada tabel 1 .
Tabel 1 Susunan Acara

\begin{tabular}{|c|c|c|}
\hline No & Waktu & Kegiatan \\
\hline 1 & $\begin{array}{c}08.00- \\
08.30\end{array}$ & $\begin{array}{l}\text { Persiapan } \\
\text { (Dosen) }\end{array}$ \\
\hline 2 & $\begin{array}{c}08.30- \\
08.45\end{array}$ & $\begin{array}{l}\text { Sambutan dari Wakil } \\
\text { Rektor III }\end{array}$ \\
\hline 3 & $\begin{array}{l}08.45- \\
09.00\end{array}$ & $\begin{array}{l}\text { Sambutan dari Ketua } \\
\text { Pengabdian } \\
\text { Masyarakat }\end{array}$ \\
\hline 4 & $\begin{array}{c}09.00- \\
12.00\end{array}$ & $\begin{array}{l}\text { Acara Inti / BIMTEK } \\
\text { pemanfaatan } \\
\text { konseling Online oleh } \\
\text { Pemateri }\end{array}$ \\
\hline 5 & $\begin{array}{l}12.00- \\
13.00\end{array}$ & $\begin{array}{l}\text { Ramam-tamah dan } \\
\text { penutupan }\end{array}$ \\
\hline
\end{tabular}

\section{PEMBAHASAN}

Pemanfaatan konseling Online yang dibangun pada dasarnya berada di bawah naungan Pusat Pelayanan Asesmen Kompetensi Pengembangan Karir (PPAKPK) Universitas Palangka Raya yang beralamat di Kantor Lembaga Pelayanan Penjaminan dan Pengembangan Mutu Pendidikan (LP3MP) Universitas Palangka Raya sebagai tempat pelayanan Asesmen resmi yang ditunjuk melalui Keputusan Rektor Universitas Palangka Raya dengan SK Rektor Universitas Palangka Raya No. 84/UN24/KP/2019.

Unit Pelayanan Asesmen Kompetensi dan Pengem-bangan Karier yang ada di Universitas Palangka Raya, bertujuan untuk berkolaborasi dalam membantu Pemerintah Daerah dan instansi swasta yang berada di Daerah Kalimantan Tengah dalam hal manejerial, pemetaan kompentasi dan pengembangan SDM untuk menunjang kemajuan dan perkembangan daerah. 
Available online at https://jurnal.stmikroyal.ac.id/index.php/jurdimas

Unit terapan ini juga menjadi mitra bagi organisasi dan masyarakat dalam hal pengembangan pendidikan dan keilmuan dalam rangka penelitian dan pengabdian kepada masyarakat guna menciptakan dan mencetak SDM yang berkualitas, profesional, dan mampu berkompetisi di Kalimantan Tengah.

Setelah dilaksanakannya kegiatan pengabdian kepada masyarakat dalam bentuk Bimtek terkait pemanfaatan konseling online pada guru SD di Kalimantan Tengah, maka diperoleh hasil kegiatan yaitu Membangun aplikasi konseling online melalui Website http://asesmenupr.id/ yang dapat diakses melalui komputer ataupun smartphone.

Konseling online ini merupakan bentuk kegiatan konseling yang dilakukan antara pengguna layanan konsultasi dengan konsumen, istilah di dalam konseling sering disebut konselor dan klien. Aplikasi yang dibuat adalah web konseling online dengan menempatkan menu akses konseling pada website. Melalui menu tersebut klien dapat mengakses kebutuhan konseling yang ingin dilakukan. Bentuk konseling yang dapat dilayani berupa konsultasi masalah individu, keluarga, pekerjaan, serta konsultasi terkait masalah umum lainnya.

Pada Bimtek pemanfaatan konseling Online yang dilaksanakan melalui zoom meeting pada tanggal 26 Oktober 2020 dofokuskan kepada pelayanan bagi Guru SD khususnya di Kalimantan Tengah yang membutuhkan aplikasi pelayanan Konseling, baik bagi dirinya ataupun bagi siswa beserta orang tua siswa itu sendiri. Dalam hal ini Guru bisa menerapkan sistem daring dalam melakukan proses penyelesaian masalah yang di alami oleh siswa. Pada tampilan awal website PPAKPK pengunjung akan melihat bentuk-bentuk layanan yang disediakan seperti Layanan Kompetensi Manajerial, Rekrutmen (Psikotes), Pendidikan, Pelatihan Pendidikan, Konseling, Training/ Pelatihan SDM, Job Analysis, serta Outbond dan Gathering.

Adapun tahap penggunaan layanan konseling online adalah sesuai dengan langkah-langkah sebagai berikut:

1. Pertama klien, mengakses website konseling online dengan link akses http://asesmenupr.id/ kemudian pilih menu Layanan Jasa kemudian pilih Konseling pada halaman utama. Tampilan halaman konseling dapat di lihat pada gambar 1 dan 2 .

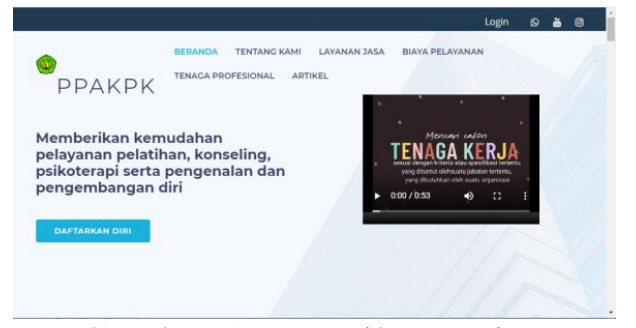

Gambar 1. Tampilan Website

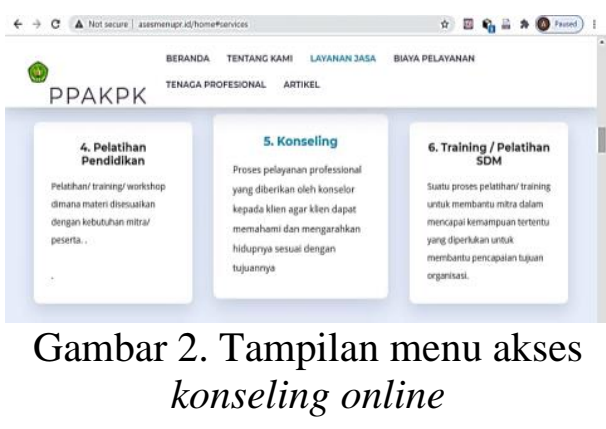

2. Setelah masuk pada halaman konseling, klien akan diberikan pilihan menu seperti layanan konseling individu, layanan konseling keluarga, layanan konseling karir dan pekerjaan, serta layanan konseling umum. Klien dapat memilih menu layanan yang dibutuhkan sesuai dengan konsultasi yang diinginkan. 
Available online at https://jurnal.stmikroyal.ac.id/index.php/jurdimas

3. Setelah memilih salah satu menu layanan di atas, klien di arahkan untuk mengakses link zoom serta beberapa media sosial yang bisa diakses seperti IG, WhatsApp, dan E-mail. Link akses ini dimaksudkan untuk memberikan ruang bebas dan tertutup bagi klien dan konselor saat melakukan konsultasi.

4. Layanan konsultasi bersifat tertutup dengan mengedepankan aspek privasi individu yang melakukan konsultasi, kecuali klien mengizinkan untuk dipublikasikan hasil konsultasinya.

\section{Melatih Guru Menggunakan Aplikasi Konseling Online Pada Saat BIMTEK}

Setelah Guru memahami penggunaan langkah-langkah dalam melakukan proses Konseling Online pada web di atas, selanjutnya Guru dapat membuat google Form untuk siswa maupun orang tua siswa yang ingin melakukan konsultasi permasalahan pendidikan anak-anak mereka. Dalam hal ini Guru hanya di berikan akses untuk memandu langkahlangkah penggunaan konseling online pada web, bukan sebagai konselor ataupun pisokolog yang telah ditetapkan oleh Tim PPAKPK UPR meskipun pada pelaksanaannya di sekolah Guru sudah menjadi tempat berkonsultasi bagi para siswa-siswinya di sekolah masingmasing karena perannya sebagai wali kelas.

Guru yang dilatih pada pelaksanaan Bimtek pemanfaatan konseling ini menjadi tutor sebaya bagi para Guru lainnya di sekolah mereka. Selain mereka juga bisa memberikan informasi lainnya terkait pelayananpelayanan yang ada pada menu layanan website PPAKPK.

\section{Evaluasi kegiatan Bimtek Peman- faatan Konseling Online}

Pelaksanaan Bimtek pemanfaatan konseling online di ikuti oleh 20 peserta yang mewakili Guru SD di Kalimantan Tengah. Peserta yang mengikuti Bimtek merupakan anggota PGRI Kalimantan Tengah dan mendapatkan fasilitas e-sertifikat, uang kuota, serta materi pelaksanaan Bimtek tanpa adanya biaya pendaftaran.

Evaluasi dari kegiatan Bimtek yang dilaksanakan mendapat respon baik dari para peserta Bimtek, bahkan melalui adanya Konseling Online ini para Guru khsususnya Guru SD yang mengalami kendala dalam hal mengatasi permasalahan siswa ataupun orang tua siswa dengan menggunakan layanan konseling online yang disediakan oleh Universitas Palangka Raya.

Pola pendidikan pada masa pandemi saat ini merubah mindset para orang tua yang selama ini menyerahkan secara penuh proses belajar mengajar kepada Guru di sekolah, namun adanya pandemi covid-19 ini memaksa para orang tua menjadi tutor dan pendidik bagi anak-anak mereka menggantikan peran guru di sekolah. Sehingga peran tersebut banyak di antara orang tua siswa yang tidak sanggup menjalani dan berakibat kekerasan dalam pembelajaran. Hal ini disebabkan salah satunya adalah keterbatasan pengetahuan orang tua dalam menyampaikan materi pembelajaran serta keterbatasan orang tua dalam memahami karakteristik anak dalam memahami pelajaran

Adapun kendala yang dihadapi pada saat pelaksanaan Bimtek pemanfaatan konseling online kapasitas jaringan internet yang tidak merata menjangkau wilayah peserta, hal ini 
Available online at https://jurnal.stmikroyal.ac.id/index.php/jurdimas

dikarenakan kondisi daerah yang masih terdapat minimnya jangkauan internet. Namun demikian, antusias peserta tidak menyurutkan semangat mengikuti Bimtek meskipun peserta sering keluarmasuk zoom pada saat pelaksanaan.

\section{SIMPULAN}

Dari pelaksanaan Bimtek Konseling Online ini dapat memberikan wawasan kepada para Guru SD yang tergabung di dalam Persatuan Guru Republik Indonesia (PGRI) Kalimantan Tengah terkait mekanisme pemanfaatan konseling yang dapat dilakukan secara daring melalui web Pusat Pelayanan Asesmen Kompetensi dan Pengembangan Karir (PPAKPK). Pemanfaatan konseling online dilakukan sebagai upaya meminimalisir adanya kekerasan dalam dunia pendidikan yang di alami oleh siswa dari para orang tua mereka yang mengalami keterbatasan pengetahuan terkait proses belajar mengajar pada masa pandemi covid-19 saat ini.

\section{DAFTAR PUSTAKA}

Latip, A. (2020). Peran literasi teknologi informasi dan komunikasi pada pembelajaran jarak jauh di masa pandemi covid-19. EduTeach: Jurnal Edukasi dan Teknologi Pembelajaran, 1(2), 108-116.

Anon. 2015. "Integrasi Teknologi Informasi Komunikasi Dalam Pendidikan: Potensi Manfaat, Masyarakat Berbasis Pengetahuan, Pendidikan Nilai, Strategi Implementasi Dan
Pengembangan Profesional." Jurnal Pendidikan Teknologi Dan Kejuruan.

Herliandry, L. D., Nurhasanah, N., Suban, M. E., \& Kuswanto, H. (2020). Pembelajaran Pada Masa Pandemi Covid-19. JTPJurnal Teknologi Pendidikan, 22(1), 65-70.

LPPM Universitas Palangka Raya, 2020. Panduan Penelitian dan Pengabdian Kepada Masyarakat. Palangka Raya : LPPM UPR.Marzuki. 2012. "Politik Pendidikan Nasional Dalam Bingkai Undang-Undang Sistem Pendidikan Nasional." Jurnal Penelitian Humaniora.

Saefulloh, Ahmad. 2018. "peran pendidik dalam penerapan internet sehat menurut islam." Al-Tadzkiyyah: Jurnal Pendidikan Islam.

Saefulloh, Ahmad. 2019. "The Use of Whatsapp Application as A Learning Method at SMP IT Nurul Ilmi Jambi." Borneo International Journal of Islamic Studies 1(2):159-76.

Suryana, D. (2017). Pembelajaran Tematik Terpadu Berbasis Pendekatan Saintifik di Taman Kanak-Kanak. Jurnal Pendidikan Anak Usia Dini, 11(1), 67-82.

Suwarsih. 2011. “Optimalisasi Pemanfaatan TIK Untuk Meningkatkan Mutu Hakiki Pendidikan (Oleh Suwarsih Madya)." Optimalisasi Pemanfaatan TIK Untuk Meningkatkan Mutu Hakiki Pendidikan.

Yaumi, Muhammad. 2018. Media Dan Teknologi Pembelajaran. 